\title{
HbA1c as indicator for dyslipidaemia, cardiovascular and atherosclerotic events in patients with metabolic syndrome
}

\author{
Haider Mohammed Fayyadh Alyasiri \\ Medicine College - Thi-Qar University
}

\begin{abstract}
$\underline{\text { Abstract }}$
Introduction: $\mathrm{HbA1c}$ is well known indicator for control of DM. We try in this study to discuss the relationship between $\mathrm{HbA1c}$ level and some atherosclerotic events and S. lipid abnormalities in patients with metabolic syndrome.

Patients and methods: 226pts involved in this study. Metabolic syndrome was assessed according to the US National Cholesterol Education Program Adult Treatment Panel III (2001) that was modified at 2004 , cross-sectional study performed in diabetes and endocrine center between 2008-2011. Parameters like Sex, races, age, job, residency, smoking had been taken into consideration, HbA1c was measured by immunoturbidimetric assay with a Cobra Integra 800 automatic analyzer (Roche Diagnostics, Basel, Switzerland) with a reference value of 4.4-6.0\%.

Conclusion: close relationship was found between HbA1c and hypertension, s.cholestrol, s. triglyceride, HDL, s. VLDL, and LDL and Increasing level of HbA1c was associated with increasing level of s. lipids, cardiovascular risk factors and severity of metabolic syndrome.

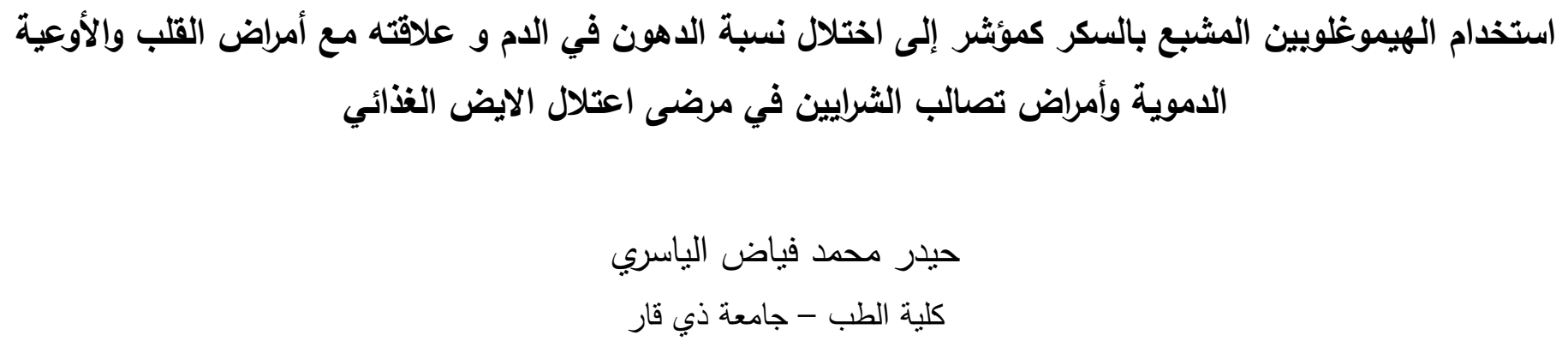

الخلاصة:

تم دراسة 226مريض من المرضى المصابين بداء السكري مع مرض اعتلال الايض الغذائي في مركز أمراض السكري والغدد الصماء في الناصرية للفترة

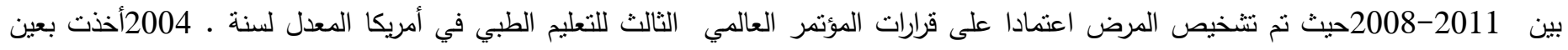
الاعتبار التاريخ المرضي الكامل والفحص السريري لكل المرضى مع إجراء تحاليل كاملة للمرضى ومن ضمنها فحص مستوى الدهون في الدم باستخدام

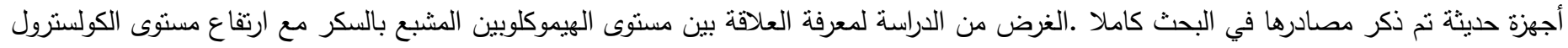

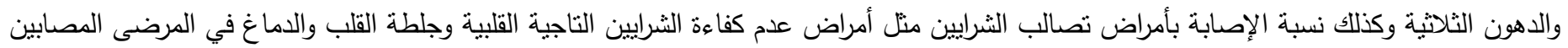

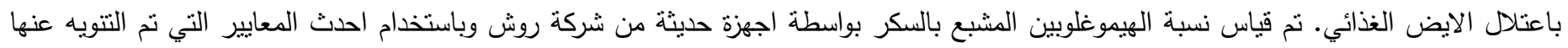
في البحث. النتائج: تبين وجود علاقة بين مستوى الهيموغلوبين المشبع بالسكري مع مستوى شدة امراض تصالب الثرايين التاجية القلبية والثرايين الدماغية و حدة مرض الايض الغذائي وكما لاحظنا ارتفاع مستوى الكولسترول والدهون الثلاثية مع ارتفاع مستوى الهيموغلوبين المشبع بالسكر . 


\section{Introduction:}

Diabetes mellitus is a common disease affects $5 \%$ of the world's population and its prevalence is doubling every generation (1). Diabetes is associated with many atherosclerotic and cardiovascular risk factors, which may be present before or after the diagnosis of diabetes (2) Normally, only a small percentage of hemoglobin in the blood (4\% to $6 \%$ ) has glucose bound to it $(3,4)$. The metabolic syndrome (MS) define as a cluster of diseases, such as hypertension, obesity, dyslipidaemia and hyperglycemia (5), some studies discuss the role between MS and cardiovascular diseases $(6,7)$ other studies found the relationship between MS and HbA1c in pre diabetic state.Evidence is accumulating that macrovascular disease is associated with lesser degrees of hyperglycemia than microvascular disease (8\&9). Cardiovascular diseases(CVD) can be found in pts with impaired glucose tolerance (IGT) (10,11).Glycated haemoglobin $\left(\mathrm{HbA}_{1 \mathrm{c}}\right)$ is widely accepted as a useful index of mean blood glucose and therapeutic guideline of diabetes. $\mathrm{HbA}_{1 \mathrm{c}}$ may predict incident cardiovascular events, even in individuals without diabetes mellitus (12-14). Kim et al. have recently reported the association of $\mathrm{HbA}_{1 \mathrm{c}}$ with metabolic syndrome and cardiovascular risk in Korean subjects(15). Thus other pro atherogenic effects of diabetes, rather than levels of glycaemia, might be related to the vascular complications of diabetes (16)(17). Recent work suggests the utility of $\mathrm{HbA1c}$ as the predictor of future risk for diabetes mellitus in diverse ethnic groups. Several recent studies suggest the use of HbA1c in the diagnosis of metabolic syndrome. Many researches have investigated the HbA1c in the diagnosis of MS.

\section{The aim of the study:}

We examined the association of HbA1c level with the MS and to predict the relationship between level of $\mathrm{HbA1c}$ and cardiovascular events and level of S.lipids in patients with metabolic syndrome, this study was done in diabetes mellitus and endocrine center in $\mathrm{AL}$ Nasiriya city.

\section{Definitions and diagnosis}

Presently there are a couple of sets defining the criteria for metabolic syndrome, set out by two different sources - the international diabetes federation (IDF) and national cholesterol education program(NCEP). These are very similar and they identify individuals with a given set of symptoms as having metabolic syndrome. There are two differences, however: the IDF state that if BMI $>30 \mathrm{~kg} / \mathrm{m} 2$, central obesity can be assumed, and waist circumference does not need to be measured. However, this potentially excludes any subject without increased waist circumference if BMI < 30. Conversely, the NCEP definition indicates that metabolic syndrome can be diagnosed based on other criteria. Also, the IDF uses geography-specific cut points for waist circumference while NCEP uses only one set of cut points for waist circumference regardless of geography. These two definitions are much more similar than the original NCEP and WHO definitions.

The NCEP-ATP III metabolic syndrome (18)definition is satisfied when more than three of the following five criteria are met:

1. Waist circumference: $\geq 90 \mathrm{~cm}$ in men, $\geq 80 \mathrm{~cm}$ in women (defined by the Western Pacific Region of WHO for obesity (WPRO) criteria(25)

\section{Hypertriglyceridaemia: $\geq 1.7 \mathrm{mmol} / 1$.}

3.Low HDL-C: $<1.0 \mathrm{mmol} / \mathrm{l}$ in males and $<1.3$ $\mathrm{mmol} / \mathrm{l}$ in females.

4.Hypertension: $\geq 130 / 85 \mathrm{mmHg}$.

5.Fasting hyperglycaemia: $\geq 5.6 \mathrm{mmol} / 1$.

\section{WHO (19)}

The world health organization criteria (1999) require presence of one of:

Diabetes mellitus,

a. Impaired glucose tolerance.

b. Impaired fasting glucose or

c. Insulin resistance.

AND two of the following:

1.Blood pressure: $\geq 140 / 90 \mathrm{mmHg}$

2.Dyslipidemia: triglycerides $(\mathrm{TG}): \geq 1.695 \mathrm{mmol} / \mathrm{L}$ and high-density lipoprotein cholesterol (HDL-C) $\leq$ $0.9 \mathrm{mmol} / \mathrm{L}$ (male), $\leq 1.0 \mathrm{mmol} / \mathrm{L}$ (female)

3.Central obesity: waist:hip ratio > 0.90 (male); $>0.85$ (female), or body mass

index $>30 \mathrm{~kg} / \mathrm{m}^{2}$

4.Microalbuminuria: urinary albumin excretion ratio $\geq$ $20 \mu \mathrm{g} / \mathrm{min}$ or

albumin:creatinine ratio $\geq 30 \mathrm{mg} / \mathrm{g}$

\section{American Heart Association/Updated NCEP}

There is confusion as to whether, in 2004, the AHA/NHLBI intended to create another set of guidelines or simply update the NCEP ATP III definition. According to Scott Grundy, University of 
Texas Southwestern Medical School, Dallas, Texas, the intent was just to update the NCEP ATP III definition and not create a new definition:(6,7)

*Elevated waist circumference:

*Men - greater than 40 inches $(102 \mathrm{~cm})$

*Women - greater than 35 inches $(88 \mathrm{~cm})$

*Elevated triglycerides: Equal to or greater than $150 \mathrm{mg} / \mathrm{dL}(1.7 \mathrm{mmol} / \mathrm{L})$

*Reduced HDL ("good") cholesterol:

*Men - Less than $40 \mathrm{mg} / \mathrm{dL}(1.03 \mathrm{mmol} / \mathrm{L})$

*Women - Less than $50 \mathrm{mg} / \mathrm{dL}(1.29 \mathrm{mmol} / \mathrm{L})$

*Elevated blood pressure: Equal to or greater than 130/85 mm Hg or use of medication for hypertension

*Elevated fasting glucose: Equal to or greater than $100 \mathrm{mg} / \mathrm{dL}(5.6 \mathrm{mmol} / \mathrm{L})$ or use of medication for hyperglycemia individuals with metabolic syndrome seemingly are susceptible to other conditions, notably polycystic ovary syndrome, fatty liver, cholesterol gallstones, asthma, sleep disturbances, and some forms of cancer(20).

\section{Patients and method:}

In this retrospective cross-sectional study: 226pts involved in this study, performed in diabetes and endocrine center in the period between 2008-2011, all patients have DM proved after fasting and random blood sugar. Parameters like Sex, races, age, job, residency, smoking had been taken into consideration, past medical, and surgical history, drug history, and duration of illness, the later was divided in to two groups more or less than 5 years, the cause of this division is that most of the complications in insulin dependent diabetes mellitus (IDDM) occur at period more than five years but there is no time limit for complication to occur in NIDDM. Height, weight, and systolic and diastolic blood pressure were measured. Blood pressure was measured with a standardized sphygmomanometer after at least $5 \mathrm{~min}$ of rest, according to the Hypertension Detection and Follow-up Program protocol. Body mass index (BMI) was calculated by dividing weight $(\mathrm{kg})$ by height $(\mathrm{m})$ squared.After a 12-h fast, blood glucose, total cholesterol, triglyceride, high-density lipoprotein cholesterol (HDL-C), low-density lipoproteincholesterol (LDL-C) and VLDL, blood urea and serum creatinine levels were measured using the hexokinase method (AU 5400 Autoanalyser; using minividas instrument (made in Italy). The patients were investigated for $\mathrm{Hb}, \mathrm{HbA} 1 \mathrm{c}$. HbA1c was measured with high-performance liquid chromatography (HLC-723
G7; Tosoh Corporation, Tokyo, Japan) according to the standardized Diabetes Control and Complications Trial assay. GUE was done also for every patient. Body mass index was divided into five groups $(<20,20-24.9,25-$ 29.9, 30-34.9, and >35). HbA1c was divided into three groups $(<7,7-7.9,>8)$. History of atherosclerosis including history of coronary artery disease, CVA, peripheral arterial insufficiency. Fasting blood samples were obtained for blood sugar (venous blood samples taken after overnight fast of a minimum of $8 \mathrm{hrs}$.). The kit used for biochemistory was biomerieux (France) while the kit used for blood sugar was randox, s.cholestrol and s.triglyceride was bioLABO, other component of lipid profile had been studied also. 111 patients had metabolic syndrome and 115 had no metabolic syndrome. Metabolic syndrome was assessed according to the US National Cholesterol Education Program Adult Treatment Panel III (2001) that was modified at 2004.(5) $\mathrm{HbA}_{1 \mathrm{c}}$ was measured by immunoturbidimetric assay with a Cobra Integra 800 automatic analyzer (Roche Diagnostics, Basel, Switzerland) with a reference value of $4.4-6.0 \%$. The methodology was aligned with the Diabetes Control and Complications Trial (DCCT) and National Glycohemoglobin Standardization Program (NGSP) standards (9).general urine examination was assessed and including glycosuria and albuminuria the benefit from measuring albuminuria is that some studies use it for definition of metabolic syndrome. The level of significance was chosen as $\mathrm{P}<0.05$. All analyses were carried out with the statistical program SPSS for Windows v. 7.

\section{Exclusion criteria:}

We exclude all patients with anemia, or hemoglobinopathies because $\mathrm{HbAlc}$ is frequently misleading in patients with some types of anemia and hemoglobinopathies and there are some problems in standardization of HbAlc measurement. However, the worldwide standardization of $\mathrm{HbA} 1 \mathrm{c}$ measurement has significantly reduced the bias between them.

\section{Results:}

HbA1c and the patients general parameters: (table 1)

226 patients included in this study, all of them suffered from DM. 100(44.2)\% patients were male and $126(55.8 \%)$ patients were female and we find increase number of patients with increase level of $\mathrm{HbA} 1 \mathrm{c}$ in both sex $(\mathrm{p}=0.026)$. Their age range from $4(1.8 \%)$ for those $<15 \mathrm{y}$ to $143(63.2 \%)$ for those $>45 \mathrm{y}$. Number of 
patients with high level of HbA1c increase with increasing age $(\mathrm{p}=0.015)$.

\section{The relationship between HbA1c and metabolic syndrome and its parameters:}

Hypertension: was taken in consideration as it is one of the cornerstones of metabolic syndrome definition. In table3: (71) patients had a history of hypertension and $155 \mathrm{pt}$ were non hypertensive, number of patients with high level of $\mathrm{HbA1c}$ increase gradually in both groups which was very significant statistically $(\mathrm{p}=0.000)$.

Body mass index: $82(36 \%)$ pt had body mass index more than 30 , we can see from the table 4 increase number of patients with high level of $\mathrm{HbA1c}$ with increase body mass index $(\mathrm{p}=0.03)$ which is significant statistically.

S.triglyceride (table5): number of patients with $\mathrm{S}$ triglyceride level $>200 \mathrm{mg} \backslash \mathrm{dl}$ was $72(31.9 \%)$ and those with level <200mgldl was $154(68.1 \%)$ still with increase number of patients with high level of $\mathrm{HbA1c}$ in both groups $(p=0.001)$ which is very significant. $S$. HDL it is clear from the table 6; there is $135(59.7 \%)$ patients with dangerous lipid $<40$ for male and $<50$ for female. And a good relationship between $\mathrm{HbA} 1 \mathrm{c}$ and HDL as there is increase number of patient with high level of HbA1c and bad lipid $(\mathrm{p}=0.002)$.

S.cholesterol: $129(57.1 \%)$ pt. had S.cholesterol $>180 \mathrm{mgldl}$ from the whole studied pts.(table 7) and still there is increase in the number of pts with high levels of $\mathrm{HbA1c}$ in pt with high S.cholesterol and the level of HbA1c increase gradually. This is statistically significant $(\mathrm{p}=0.033)$.

Metabolic syndrome(table 2): 111(49.1\%)pts had metabolic syndrome, and we can see from the table there is increase in the number of pts with $\mathrm{HbA} 1 \mathrm{c}$ and metabolic syndrome in steady state which is not very clear in pts without metabolic syndrome and this is statistically very significant $(\mathrm{p}=0.000)$.

According to the previous studied parameters S.triglyceride, S.HDL, BMI, hypertension have strong relationship to HbA1c level and we can see there is a great relationship between metabolic syndrome and $\mathrm{HbA} 1 \mathrm{c}$ and in relation to $\mathrm{HbA1c}$, the number of pts increase gradually in all parameters of metabolic syndrome, and DM become worse and badly controlled. we can see now in pt with badly controlled DM the lipid profile, BMI, hypertension become worse also, and this is can be easily understood with insulin resistant in metabolic syndrome pt and obesity.

\section{Relationship of HbA1c with other parameters}

S.LDL has a significant relationship with HbA1c $(\mathrm{p}=0.049)$

Albuminuria which is important as it is one of the parameters in the diagnosis of metabolic syndrome in some studies like WHO criteria (1999). We study only the ordinary macro albuminuria because micro albuminuria need more sophisticated methods and still we have 20 pts involved with albumin urea and there is good relationship with $\mathrm{HbA1c}(\mathrm{p}=0.026)$.

Glycosuria is greatly related to the HbA1c $(\mathrm{p}=0.0000)$.

$\mathrm{S}$.VLDL increasing in level in pt with metabolic syndrome and still a steady increase in HbAlc level can be seen clearly although the value $\mathrm{p}=0.063$.

We divide the patients according to the type of the drugs that was used. 29(12.8\%) pt use insulin therapy for their disease, $6(2.7 \%)$ on diet control only while the others, were on oral therapy. 134(59.3\%) pts diagnosed less than five years and 92(40.7\%) diagnosed more than five years as duration of the disease diagnosis and $\mathrm{HbA1c}$ also taken in consideration with increase number of patients with high level of HbA1c in both groups $(p=0.051)$. The same results was found with the UTI $(0.000)$, work $(\mathrm{p}=0.011), \operatorname{smoking}(\mathrm{p}=0.061)$ although these parameters are not included in the original subject but by the way we mention them. $17(7.5 \%)$ pt had a history of atherosclerosis like CVA, CHD, or peripheral artery disease. Although few patients had atherosclerosis still there is good relationship with $\mathrm{HbA1c}(\mathrm{p}=0.000)$.

\section{Discussion:}

Few studies in the world discuss the relationship between one or more of the parameters of the metabolic syndrome with $\mathrm{HbA} 1 \mathrm{c}$ and serum lipid abnormalities but in our studies we discuss all the parameters collectively.Metabolic syndrome is a collection of several risk factors all of the share in the development or exaggeration of atherosclerosis. Diabetes mellitus form the corner stone of it. Good control DM and follow up by HbA1c give a good chance for the other factors to be controlled also. We find in this study that there is good relationship between HbA1c level and the serum level of lipid profiles, therefore, decrease $\mathrm{HbA} 1 \mathrm{C}$ decreases the level lipid profile, this is also found in several studies like Singh"s study(21) who also found the same results, and he concluded that $\mathrm{HbA1c}$ could be used as a predictor for dyslipidaemia and then cardiovascular diseases. 
In our study we compare levels of $\mathrm{HbA} 1 \mathrm{c}$ between patients who has metabolic syndrome and those without metabolic syndrome, we find steady increase in its level indicate those diabetic obese patients with HT, hypertriglyceridaemia, and decrease HDL had poor control DM, this can be explained also as patients with metabolic syndrome usually have insulin resistant .This picture of dyslipidaemia can be followed up by frequent checking of HbAlc in addition to lipid profile. this is also agreed by other studies like Khan"s et al study(22) who conclude that $\mathrm{HbA1c}$ predict dyslipidaemia. We discuss also the relationship between level of $\mathrm{HbA1c}$ and history of atherosclerotic complications like myocardial infarction, cerebrovascular diseases and peripheral vascular diseases we find strong relationship between them as it is logical to find these complication in patients with poor control DM in other words high HbA1c. this is also found in Yang"s et al (23) who studied also that $\mathrm{HbA} 1 \mathrm{c}$ is a predictor for clinical and subclinical atherosclerotic complications. Regarding the body mass index we find bad controlled DM which is reflected by high level of HbAlc and increasing body mass index this can be explained by increase incidence of insulin resistance in those patients this agree with the previous study by Patiakas, S1; Charalampous, who discuss the obesitycorrelation between the glycated hemoglobin (hbalc) level, the arterial blood pressure (ap) and the body mass index (bmi) in diabetic patients, and evaluation of its utility (24). In our study we find good relationship between elevated HbA1c and high s. triglyceride, this is well known as elevated blood triglycerides are the most common lipid (blood fat) disorder in people with prediabetes or diabetes. This is also agreed with Mayo clinic proceedings).(25). Therefore, monitoring triglycerides is essential in order to avoid the macro vascular complications - heart attacks, strokes, and limb amputations in the future.

\section{Conclusion:}

1.Good relationship between $\mathrm{HbA1c}$ and hypertension, s.cholestrol, s. triglyceride, HDL, s. VLDL, and LDL was found

2.HbA1c is good predictor for large body mass index.

3. Increasing $\mathrm{HbAlc}$ was associated with increasing cardiovascular risk factors, so that $\mathrm{HbAlc}$ might be predictive factor for the future development of cardiovascular risk factors.
4. Increase in level of $\mathrm{HbA} 1 \mathrm{c}$ with increasing level of serum lipids profile

5. HbA1c can be used as a predictor for the severity of metabolic syndrome.

6. HbA1c can give a good idea about the early development of atherosclerotic processes.

7.HbA1c can be changed with change in body mass index.

8.For every patient with high HbA1c we must check lipid profile.

(Table 1): Characters of the studied patients

\begin{tabular}{|c|c|c|}
\hline Characters of the patients & Details of the characters & Numbers of the patients \\
\hline \multirow[t]{2}{*}{ Sex } & Males & $100(44.2 \%)$ \\
\hline & Female & $126(55.8 \%)$ \\
\hline \multirow[t]{2}{*}{ Ase } & Less than $15 y$ & $4[1.8 \%]$ \\
\hline & $15-45 y$ & $79(35 \%)$ \\
\hline \multirow{2}{*}{ Duration of disease } & Less than $5 y$ & $13459.3 \%$ \\
\hline & More than 5 years & $92(40.796)$ \\
\hline \multirow[t]{2}{*}{ Residency } & Urban & $126(55.8 \%)$ \\
\hline & rural & $100(44.2 \%$ \\
\hline \multirow[t]{3}{*}{ Work } & Home worker & $124(54.9 \%)$ \\
\hline & Employ & $47(20.899)$ \\
\hline & Free work & $55(24.396)$ \\
\hline \multirow[t]{2}{*}{ Smoking } & Smoker & $23(10.2 \%)$ \\
\hline & Not smoker & $203(89.8 \%$ \\
\hline \multirow[t]{2}{*}{ Hypertension } & Hypertensive & $71(31.496)$ \\
\hline & Not hypertensive & $155(68.6 \%)$ \\
\hline \multirow[t]{2}{*}{ Atheroseleros is } & Atheroseleros is & $17(7.5 \%)$ \\
\hline & Non atheros derosis & $209(92.5 \%)$ \\
\hline \multirow[t]{3}{*}{ HbA1C } & Less than 7 & $52(23 \%)$ \\
\hline & $7-7.9$ & $26(11.5 \%)$ \\
\hline & More than 8 & $148 ; 65.5 \%]$ \\
\hline \multirow[t]{2}{*}{ Family history } & +ve & $45(19.9 \%)$ \\
\hline & $-w e$ & $181(80.1 \%)$ \\
\hline \multirow[t]{5}{*}{ Body mass index } & $<20$ & $6(2.7 \%)$ \\
\hline & $20-24.9$ & $50(22.199)$ \\
\hline & $25-29.9$ & 88 (38.996) \\
\hline & $30-34.9$ & $48(21.296)$ \\
\hline & $>35$ & $34(15 \%)$ \\
\hline \multirow[t]{5}{*}{ Type of drugs } & Oral sulfonylurea drugs & $95(42 \%)$ \\
\hline & Oral metformin & $23(10.29)\}$ \\
\hline & Sulfonyluria +metformin & $73(32.399)$ \\
\hline & Insulin therapy & $29(12.899)$ \\
\hline & Diet control only & $6(2.7 \%)$ \\
\hline \multirow[t]{2}{*}{ UTI } & +ve & $72(31.998)$ \\
\hline & $-\mathrm{we}$ & $154(68.1 \%)$ \\
\hline \multirow[t]{3}{*}{ S.cholestrol } & $\times 240 \mathrm{mg}$ idl & $46(20.496)$ \\
\hline & $180-240 \mathrm{mg} l \mathrm{dl}$ & $83(36.799$ \\
\hline & $<180 \mathrm{mgldl}$ & $97(42.99)$ \\
\hline \multirow[t]{2}{*}{ S.triglyceride } & $\times 200 \mathrm{mg}$ ld & $72(31.9 \%)$ \\
\hline & $<200 \mathrm{mg} \mid \mathrm{dl}$ & $154[68.1 \%]$ \\
\hline \multirow[t]{2}{*}{$\mathrm{HDL}$} & $<40 \mathrm{mg} / \mathrm{d} \mid(\mathrm{m})<5 \mathrm{O} / \mathrm{f})$ & $135(59.7 \%)$ \\
\hline & $>40 \mathrm{mg} \backslash \mathrm{d} \mid(\mathrm{m})>50(\mathrm{f})$ & $91(40.399)$ \\
\hline \multirow[t]{2}{*}{ VLDL } & $\times 35 \mathrm{mg}$ idd & $98(43.459)$ \\
\hline & $<35 \mathrm{mg}$ idl & $128(56.6 \%)$ \\
\hline \multirow[t]{2}{*}{$\overline{L D L}$} & $\times 130 \mathrm{mg}$ idl & $86(38.19)$ \\
\hline & $<130 \mathrm{mg}$ idl & $140 \mid 61.99$ \\
\hline \multirow[t]{2}{*}{ Type of DM } & NIDDM & $196(86.7 \%)$ \\
\hline & $\begin{array}{l}\text { IDDM } \\
\text { diet }\end{array}$ & $\begin{array}{l}28(12.499) \\
2(0.996)\end{array}$ \\
\hline \multirow{2}{*}{ Metabolic syndrome } & twe & $111 / 49.1 \%$ \\
\hline & $-w e$ & $115 / 50.9 \%$ \\
\hline \multirow[t]{2}{*}{ Albuminuria } & twe & $22(9.7 \%)$ \\
\hline & -we & $204(90.3 \%)$ \\
\hline
\end{tabular}




\section{Relationship between HbA1c and the patient's parameters}

(Table 2): Relationship between HbA1c and metabolic syndrome $(\mathrm{p}=0.000)$

\begin{tabular}{|c|c|c|c|c|c|}
\hline \multicolumn{6}{|l|}{ Crosstab } \\
\hline \multicolumn{6}{|l|}{ Count } \\
\hline & & \multicolumn{3}{|c|}{$\mathrm{HbA1c}$} & \multirow[b]{2}{*}{ Total } \\
\hline & & $<7$ & $7-7.9$ & $>8$ & \\
\hline \multirow[t]{2}{*}{ Metabolic Syndrome } & metabolic synd. pt & 8 & 20 & 83 & 111 \\
\hline & non metabolic synd pt & 44 & 6 & 65 & 115 \\
\hline \multicolumn{2}{|l|}{ Total } & 52 & 26 & 148 & 226 \\
\hline
\end{tabular}

(Table 3): Relationship between HT and

\begin{tabular}{|c|c|c|c|c|c|}
\hline \multicolumn{6}{|c|}{ Crosstab } \\
\hline \multicolumn{6}{|c|}{ Count } \\
\hline & & \multicolumn{3}{|c|}{$\mathrm{HbA1c}$} & \multirow[b]{2}{*}{ Total } \\
\hline & & $<7$ & $7-7.9$ & $>8$ & \\
\hline \multirow[t]{2}{*}{$\mathrm{HT}$} & hypertensive pt & 27 & 9 & 35 & 71 \\
\hline & not hypertensive pt & 25 & 17 & 113 & 155 \\
\hline \multicolumn{2}{|c|}{ Total } & 52 & 26 & 148 & 226 \\
\hline
\end{tabular}

(Table 4): Characters of the studied patients

\begin{tabular}{|c|c|c|c|c|c|}
\hline \multirow{2}{*}{\multicolumn{6}{|c|}{\begin{tabular}{|l} 
Crosstab \\
Count
\end{tabular}}} \\
\hline & & & & & \\
\hline & & \multicolumn{3}{|c|}{ HbA1c } & \multirow[b]{2}{*}{ Total } \\
\hline & & $<7$ & $7-7.9$ & $>8$ & \\
\hline \multirow[t]{5}{*}{ bodyMassIndex } & $<20$ & 2 & 0 & 4 & 6 \\
\hline & \begin{tabular}{|l}
$20-24.9$ \\
\end{tabular} & 9 & 7 & 34 & 50 \\
\hline & \begin{tabular}{|l|}
$25-29.9$ \\
\end{tabular} & 25 & 6 & 57 & 88 \\
\hline & $30-34.9$ & 9 & 9 & 30 & 48 \\
\hline & $>35$ & 7 & 4 & 23 & 34 \\
\hline \multicolumn{2}{|l|}{ Total } & 52 & 26 & 148 & 226 \\
\hline
\end{tabular}

(Table 5): S.Triglyceride and $\mathrm{HbA1c}(\mathrm{p}=0.001)$

\begin{tabular}{|l|l|l|l|l|l|}
\hline \multicolumn{5}{|l|}{ Crosstab } \\
\hline Count & \multicolumn{4}{l|}{} \\
\hline & & HbA1c & \\
\hline & $<7$ & $7-7.9$ & $>8$ & Total \\
\hline \multirow{3}{*}{ S.triglyceride } & $=200 \mathrm{mgldl}$ & 7 & 11 & 54 & 72 \\
\cline { 2 - 6 } & $<200 \mathrm{mgldl}$ & 45 & 15 & 94 & 154 \\
\hline Total & 52 & 26 & 148 & 226 \\
\hline
\end{tabular}

(Table 6): HDL and $\mathrm{HbA} 1 \mathrm{c}(\mathrm{p}=0.002)$

\begin{tabular}{|c|c|c|c|c|c|}
\hline \multicolumn{6}{|c|}{ Crosstab } \\
\hline \multicolumn{6}{|c|}{ Count } \\
\hline & & \multicolumn{3}{|c|}{ HbA1c } & \multirow[b]{2}{*}{ Total } \\
\hline & & $<7$ & $7-7.9$ & $>8$ & \\
\hline \multirow[t]{2}{*}{ HDL } & $<40 \mathrm{~m},<50 \mathrm{f}$ & 22 & 17 & 96 & 135 \\
\hline & $>40 \mathrm{~m},>50 \mathrm{f}$ & 30 & 9 & 52 & 91 \\
\hline \multicolumn{2}{|l|}{ Total } & 52 & 26 & 148 & 226 \\
\hline
\end{tabular}

(Table7): S.Cholestrol and HbA1c $(\mathrm{p}=0.033)$

\begin{tabular}{|c|c|c|c|c|c|}
\hline \multicolumn{6}{|l|}{ Crosstab } \\
\hline \multicolumn{6}{|l|}{ Count } \\
\hline & & \multicolumn{3}{|c|}{$\mathrm{HbA1c}$} & \multirow[b]{2}{*}{ Total } \\
\hline & & $<7$ & $7-7.9$ & $>8$ & \\
\hline \multirow[t]{3}{*}{ S.cholestrol } & $>240 \mathrm{mgldl}$ & 10 & 5 & 31 & 46 \\
\hline & $180-240 \mathrm{mgldl}$ & 18 & 8 & 57 & 83 \\
\hline & $<180 \mathrm{mgldl}$ & 24 & 13 & 60 & 97 \\
\hline \multicolumn{2}{|l|}{ Total } & 52 & 26 & 148 & 226 \\
\hline
\end{tabular}

(Table 8): Atherosclerosis and HbA1c $(\mathrm{p}=0.000)$

\begin{tabular}{|c|c|c|c|c|c|}
\hline \multicolumn{6}{|l|}{ Crosstab } \\
\hline \multicolumn{6}{|l|}{ Count } \\
\hline & & \multicolumn{3}{|c|}{$\mathrm{HbA1 \textrm {c }}$} & \multirow[b]{2}{*}{ Total } \\
\hline & & $<7$ & $7-7.9$ & $>8$ & \\
\hline \multirow[t]{2}{*}{ atherosclerosis } & atherosclerosis & 11 & 1 & 5 & 17 \\
\hline & \begin{tabular}{|l} 
not atherosclerosis \\
\end{tabular} & 41 & 25 & 143 & 209 \\
\hline \multicolumn{2}{|l|}{ Total } & 52 & 26 & 148 & 226 \\
\hline
\end{tabular}

(Table 9): VLDL AND HbA1c $(\mathrm{p}=0.063)$

\begin{tabular}{|c|c|c|c|c|c|}
\hline \multicolumn{6}{|c|}{ Crosstab } \\
\hline \multicolumn{6}{|l|}{ Count } \\
\hline & & \multicolumn{3}{|c|}{$\mathrm{HbA1c}$} & \multirow[b]{2}{*}{ Total } \\
\hline & & $<7$ & $7-7.9$ & $>8$ & \\
\hline \multirow[t]{2}{*}{ VLDL } & $>35 \mathrm{mgldl}$ & 21 & 14 & 63 & 98 \\
\hline & $<35 \mathrm{mgldl}$ & 31 & 12 & 85 & 128 \\
\hline \multicolumn{2}{|l|}{ Total } & 52 & 26 & 148 & 226 \\
\hline
\end{tabular}

(Table 10): LDL and HbA1c(0.049)

\begin{tabular}{|l|l|l|l|l|l|}
\hline \multicolumn{5}{|l|}{ Crosstab } \\
\hline \multicolumn{2}{|l|}{ Count } & \multicolumn{5}{l}{} \\
\hline & & HbA1c & \\
\hline & & $<7$ & $7-7.9$ & $>8$ & Total \\
\hline \multirow{3}{*}{ LDL } & $>130 \mathrm{mgldl}$ & 22 & 10 & 54 & 86 \\
\cline { 2 - 6 } & $<130 \mathrm{mgldl}$ & 30 & 16 & 94 & 140 \\
\hline Total & 52 & 26 & 148 & 226 \\
\hline
\end{tabular}

(Table 11): Albuminuria and HbA1c $(p=0.026)$

\begin{tabular}{|l|l|l|l|l|l|}
\hline \multicolumn{5}{|l|}{ Crosstab } \\
\hline Count & & HbA1c & \\
\hline & & $<7$ & $7-7.9$ & $>8$ & Total \\
\hline & & 9 & 1 & 12 & 22 \\
\hline \multirow{3}{*}{ albuminUria } & $+\mathrm{ve}$ & 9 & 25 & 136 & 204 \\
\cline { 2 - 5 } & $-\mathrm{ve}$ & 43 & 26 & 148 & 226 \\
\hline Total & 52 &
\end{tabular}




\section{$\underline{\text { References }}$}

1. Lind,M,Oden,A.,Fahlen,M.,Eliasson,B.a systemic review of HbAlc variables used in the study of diabetic complications Diabetes \& Metabolic Syndrome: Clinical Research \& Reviews. Year: 2008 ;Volume: 2 Issue: 4 Pages: 282-293.

2.Bernal-Lopez, Villalobos-Sanchez, Mancera-Romero, Jansen-Chaparro et al.Why not use the HbA1c as a criterion of dysglycemia in the new definition of the metabolic syndrome? Impact of the new criteria in the prevalence of the metabolic syndrome in a Mediterranean urban population from Southern Europe (IMAP study. Multidisciplinary intervention in primary care) : Diabetes Research and Clinical Practice. Year: 2011; Volume: 93 Issue: 2 Pages: e57-e60.

3. Hamman RF. Genetic and environmental determinants of non-insulin-dependent diabetes mellitus (NIDDM) Diabetes Metab Rev. 1992;8:287-338.

4. Castelli WP. Epidemiology of coronary heart disease: the Framingham Study. Am J Med. 1984;76:4-12.

5. Esteghamati, A., Khalilzadeh, O,.Anvari, M., Ahadi, M.S. Oet al..Metabolic Syndrome and Insulin Resistance Significantly Correlate with Body Mass Index. Archives of Medical Research .Year: 2008 ;Volume: 39: Issue: 8 Pages: 803808 .

6. Reaven GM. Role of insulin resistance in human disease. Diabetes. 1988;37:1595-1607.

7. DeFronzo RA, Ferrannini E. Insulin resistance: a multifaceted syndrome responsible for NIDDM, obesity, hypertension, dyslipidemia, and atherosclerotic cardiovascular disease. Diabetes Care. 1991;14:173-194.

8. Coutinho M, Gerstein HC, Wang Y, Yusuf S. The relationship between glucose and incident cardiovascular events. A metaregression analysis of published data from 20 studies of 95783 individuals followed for 12.4 years. Diabetes Care. 1999;22:233-240.
9. Decode Study Group. Glucose tolerance and cardiovascular mortality: comparison of fasting and 2-hour diagnostic criteria. Arch Intern Med. 2001;161:397-405.

10. Groot L, Ortho-Melander M. The dysmetabolic syndrome. Intern Med. 2001;250:105-120.

11. Unwin N, Shaw J, Zimmet P, Alberti KG. Impaired glucose tolerance and impaired fasting glycaemia: the current status on definition and intervention. Diabet Med. 2002;19:708-723.

12. Park S, Barrett-Connor E, Wingard DL, Shan J, Edelstein $\mathrm{S}$. $\mathrm{GHb}$ is a better predictor of cardiovascular disease than fasting or postchallenge plasma glucose in women without diabetes: the Rancho Bernardo Study. Diabetes Care. 1996;19:450-456.

13. de Vegt F, Dekker JM, Ruhe HG, Stehouwer CD, Nijpels G, Bouter LM, et al. Hyperglycaemia is associated with all-cause and cardiovascular mortality in the Hoorn population: the Hoorn Study. Diabetologia. 1999;42:926-931.

14. Khaw KT, Wareham N, Luben R, Bingham S, Oakes S, Welch A, et al. Glycated haemoglobin, diabetes, and mortality in men in Norfolk cohort of European Prospective Investigation of Cancer and Nutrition (EPIC-Norfolk) BMJ. 2001;322:15-18.

15. 19. Kim, H.K. - Kim, C.H. - Kim, H. Bae, .J. et al. Usefulness of hemoglobin A1c as a criterion of dysglycemia in the definition of metabolic syndrome in Koreans. Diabetes Research and Clinical Practice: 2012; Volume: 95 Issue: 3 Pages: 333-339.

16. Edelman D, Olsen MK, Dudley TK, Harris AC, Oddone EZ. Utility of hemoglobin A1c in predicting diabetes risk. J Gen Intern Med. 2004;19:1175-1180.

17. Rijpert, M. Evers, I.M. de Valk, H.W. de Vroede, M.A.M.J. et al .Cardiovascular and metabolic outcome in 6-8year old offspring of women with type 1 diabetes with near-optimal glycaemic control during pregnancy Early Human 
Development,Year: 2011; Volume: 87 Issue: 1 Pages: 49-54.

18. Grundy SM, Cleeman JI, Daniels SR, Donato KA, Eckel RH, Franklin BA, et al. American Heart Association; National Heart, Lung, and Blood Institute. Diagnosis and management of the metabolic syndrome: an American Heart Association/National Heart, Lung, and Blood Institute Scientific Statement. Circulation. 2005; 112:2735-2752.

19.Vikas Veeranna, Krithi Ramesh, Sandip K. Zalawadiya et al, Glycosylated Hemoglobin and Prevalent Metabolic Syndrome in Nondiabetic Multiethnic U.S. Adults.Journal Metabolic Syndrome and Related Disorders. October 2011; 9(5): 361-367.

20. 1Scott M. Grundy, H. Bryan Brewer, 1James I. Cleeman, Sidney C. Smith . Report of the National Heart, Lung, and Blood Institute/American Heart Association NHLBI/AHA Conference Proceedings ,Conference on Scientific Issues Related to Definition . Circulation. 2004; 109: 433-438 .

21. Singh. G and Kumar. A et al. relationship among $\mathrm{HbA} 1 \mathrm{c}$ and lipid profile in Punajbi type 2 diabetic population. Journal of exercise science and physiotherapy.2011; vol. 7. No.2:99-102.

22. Khan H. A. association between glycaemic control and serum lipid profile in type 2 DM patients.HbA1c predicts dyslipidaemia. Clin. Exp. Med. 7: 24-29.

23. Yang et al. association of $\mathrm{HbA} 1 \mathrm{c}$ variability with atherosclerosis . simple marker, risk factor or statistical bias? Journal of diabetes and its complications. 2015. August, vol. 29. Issue 6:page 745-746.

24. Patiakas, S; Charalampous, C. Obesity correlation between the glycated hemoglobin (hbalc) level, the arterial blood pressure (ap) and the body mass index (bmi) in diabetic patients, and evaluation of its utility. Journal of Hypertension:June 2010,Volume 28 : Issue page 300.
25.John's et al. Hyperlipidemia and diabetes mellitus. Mayo Clinic Proceedings 73:969-976, 1998. 